\title{
Computational Modeling of Government Policy to Attain Long-Term Higher Voter Turnout for Sustainable Democracy
}

\author{
Mizan Rahman \\ School of Computational Science \& Engineering, The Sam Nunn School of \\ International Affairs, Georgia Institute of Technology, Atlanta, USA \\ Email: mizan.rahman@m2sys.com
}

Received March 23, 2013; revised April 25, 2013; accepted May 20, 2013

Copyright (C) 2013 Mizan Rahman. This is an open access article distributed under the Creative Commons Attribution License, which permits unrestricted use, distribution, and reproduction in any medium, provided the original work is properly cited.

\begin{abstract}
People power is the fundamental concept of democracy and power of the people is exercised though voting. People decide who should be elected to make decisions for them. However, if people do not properly participate in the voting process and only two-thirds of all eligible voters participate in an election, the democratic institution loses its credibility and becomes vulnerable. This paper investigates various changes in voting institutions throughout the USA with a simulation model that analyzes the efficacy of such methods to attain higher voter turnout.
\end{abstract}

Keywords: Modeling Public Policy; Sustainable Democracy; Computer Simulation; Voter Turnout; Voter Registration; Public Policy Simulation

\section{Introduction}

Democracy is generally defined as a form of government in which all people have an equal say in the decisions that affect their lives [1]. But all people should be involved in a decision process and exercise their rights to prevent the selected few from controlling the system by proxy. The USA has the lowest voter turnout rate in the world [2]. While more than 90 percent of people cast their votes in Australia, Malta, Chile and Luxemburg, only 40 percent of citizens cast their votes in America [2] (Table 1). Data (Figure 1) also show that young Americans vote less often than those people over 65 years old. Low voter turnout rate and active voter concentration in a certain age group is a serious threat to American democracy: interest groups can easily influence the outcome though media outlets or crafting policies which benefit a certain age group. To ensure our democracy is protected, I developed this model to improve voter turnout uniformly among the entire adult population.

Voter turnout data (Figure 2) from 2000 to 2010 show that about 10 - 15 percent more Americans participate in voting during a presidential election than during a midterm election. From historical evidence, we observe that the midterm congressional power switching causes the incumbent president to waste the rest of their presidency fighting back and forth with the newly elected congress; the president can hardly work on the projects and promises he was elected for. Therefore, we can conclude that a low midterm election turnout causes more damages to our system than we anticipate.

America's voter turnout problem is among the worst of any established democracy [3]. During each election we observe major voter registration efforts launched by various parties and organizations. Despite these efforts, the turnout rate remains constant during last the two decades. Many new democracies are emerging and they look-up to countries like USA for guidance. Moreover, if we can uncover a strategy, many of these new democracies can benefit from this. This project takes the USA

Table 1. Percentage of voter turnout in various countries.

\begin{tabular}{cc}
\hline Country & \% of turnout \\
\hline Russia & 61 \\
Australia, Chile, Luxemburg* & $90 \%+$ \\
Venezuela & $85 \%$ \\
Malta & \\
USA & $40 \%$ \\
\hline
\end{tabular}

Sources: Wikipedia (Data for US comes from 2010 election). 


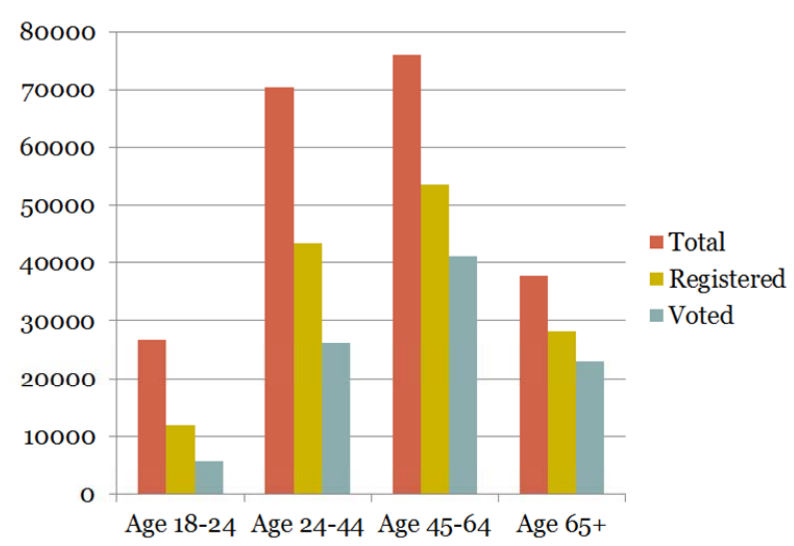

Figure 1. Voting activities among various groups (1000).

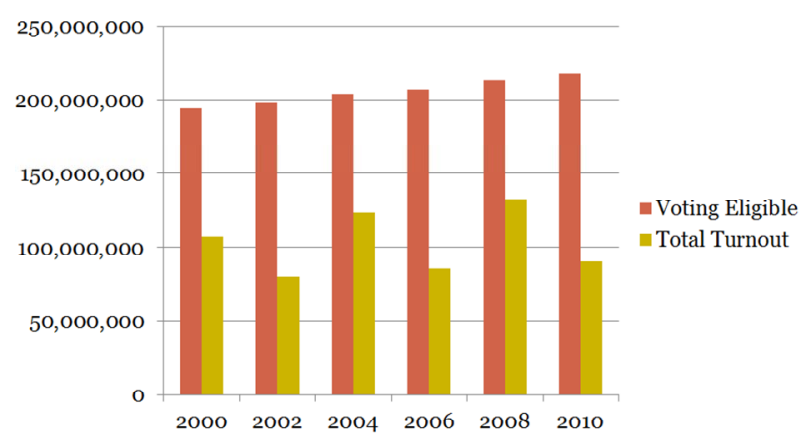

Figure 2. Voter turnouts for USA.

as a case study and investigates whether we can improve voter turnout.

Before proposing how to improve voter turnout, first we need to understand the psychology and mathematics that govern voter behavior. The basic formula for determining whether someone will vote is: $\mathrm{PB}+\mathrm{D}>\mathrm{C}$ [4].

Here, $\mathrm{P}$ is the probability that an individual's vote will affect the outcome of an election; $B$ is the perceived benefit that would be received if that person's favored political party or candidate was elected; Even though D originally stood for democracy or civic duty, currently it represents any social or personal gratification an individual gets from voting; $\mathrm{C}$ is the time, effort, and financial cost involved in voting. Since $\mathrm{P}$ is virtually zero in most elections, $\mathrm{PB}$ is also near zero, and thus $\mathrm{D}$ is the most important element in motivating people to vote. For a person to vote, these factors must outweigh C. Based on this theoretical fact, this model investigates the possibility of changing various governmental laws which can lead to D maximization.

Voter turnout is a serious topic in many countries resulting in different measures to ensure high voter turnout and adoption of the compulsory voting among the winning ones. Compulsory voting may encourage voters to research the candidates' political positions more thoroughly. Since they are voting anyway they may take more of an interest in the nature of the politicians they may vote for, rather than simply opting out. This means candidates need to appeal to a more general audience, rather than a small section of the community [5]. In the 1922 Australian federal election the voter turnout was $59.38 \%$. This was considered a very low figure and thus in 1924, Australia adopted a compulsory voting system. In the 1925 Australian federal election, the voter turnout was 91.4 percent, an increase of 32 percentage points from the previous election [6].

Even though it yields a great turnout rate, compulsory voting may seem like unnecessary pressure on people. There has been a proposal making voting mandatory in India and some people are totally furious over the idea claiming Australians were trying to repeal their own law. Many in Australia, especially some politicians, are trying to bring up the issue of repealing compulsory voting. However, in practice, popularity for compulsory voting increased around 14\% between 1943 and 2005. The Netherlands made voting compulsory between 1917 and 1967, during which time turnout was comfortably above 90 percent, similar to that for Belgium and Australia. The change to voluntary voting for the 1971 election produced an immediate fall of 15.8 percent, with the first six elections after abolition (1971-1986) producing a turnout average of 84.1 percent; the average for the most recent five elections (1989-2003) has been 78.3 percent [7]. The Netherlands figures suggest that if compulsory voting were abolished in Australia, it is likely that the turnout of voters will fall by 10 - 20 percent [7] which is much smaller than the initial gain from the compulsory mandate.

America was founded on civil liberties and any form of law that makes citizens obligated to do something is historically struck-down by the judicial system [8]. Therefore, like many other countries, a compulsory voting mechanism will not be practiced in America. Moreover, making compulsory voting would require a constitutional amendment. Amending the American constitution is a very complex process and every state must consent to such changes. Therefore, some other mechanism that does not require a compulsory voting mandate would be more practical for America.

Ease of voting and voter registration contributes to higher voter turnout. US states with no, or easier, registration requirements have larger turnouts [9]. We live in a different time of history. Instead of going to a local county office to pay taxes or visiting the DMV office for registration renewal, we achieve such tasks electronically by sitting in front of our computers. Studies show 21.5 percent Americans did not vote in 1996 because of their busy schedule [10].

My proposed model consists of improving voter turnout based on changing existing processes and policies. 
Process improvement of this model suggests implementing an e-voting system. Many countries are adopting e-voting and biometric identification based e-voting system to ensure greater participation [11]. E-voting will allow people to cast their vote from anywhere. It will also attract voters between the ages of 18 and 24 who traditionally participate the least in the voting process. If the government adopts a widespread computer and mobile based voting process, a big percentage of people [10] will not encounter a time shortage to cast their vote. For policy improvement, this model proposes easily adoptable policies. Similar to the Selective Service registration requirement, this model incorporates policies that require people have a voting record in order to collect social security, welfare and other education related benefits.

\section{Model}

In this modeling project, I am proposing the idea of making people vote though alternative law changes instead of compulsory voting. For example, to ensure personnel availability during war time, the United States adopted a law mandating all citizen between age 18 and 26 must register for Selective Service. The Selective Service System is a means by which the United States government maintains information on those potentially subject to military conscription [12]. To make this policy successful, government further mandated Registration for Selective Service as a requirement for various federal programs and benefits, including student loans, job training, federal employment, and naturalization [13]. From its establishment in 1940, the Selective Service policy under went several political high and low points including eventual abolishment in 1975 by President Ford and then re-establishment in 1980 by President Carter.

Based on the success of the Selective Service Registration and public acceptance of this mandate over time, the proposed model has incorporated similar legal changes that would require people vote instead of opting for a hopeless compulsory voting constitutional change. The proposed changes to increase voter turnout are as follows:

- Voting record mandatory for student loan;

- Voting record mandatory for social security benefit;

- Voting record mandatory for welfare assistance;

- Voting record mandatory for federal grants;

- Implement mobile/internet/electronic voting.

If the government follows these recommendations and adopts these changes, the proposed model indicates (Figure 3) voter participation will jump as lawmakers adopt various changes requiring people vote and requiring local and state government make electronic voting available. However, such legal changes and desired system outcomes are only possible in theory. In the real world, not

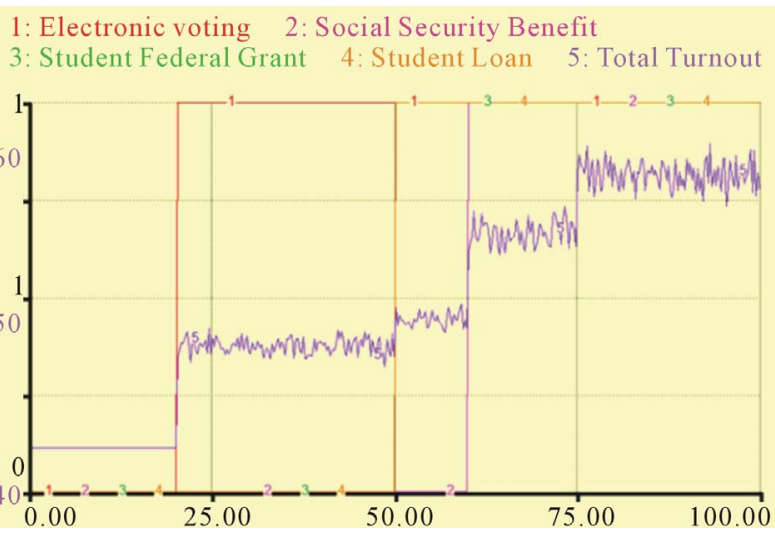

Figure 3. Simple model increases turnout.

everyone favors high voter turnout. There will be constant impediments to either abolish these policies or to interrupt the system and decrease the expected turnout. It took almost 50 years for the Selective Service Registration to not be considered propaganda against civil liberty. There is a political push to abolish compulsory voting in Australia even though $70 \%$ of the population favors it (Table 2).

This model introduces the term "indirect compulsory" which stands for making a voting record compulsory to qualify for certain government sponsored benefits. The model shows this strategy will yield similar results in the long run as it has in countries like Australia and Chile through the compulsory voting mandate. The proposed model consists of three stages:

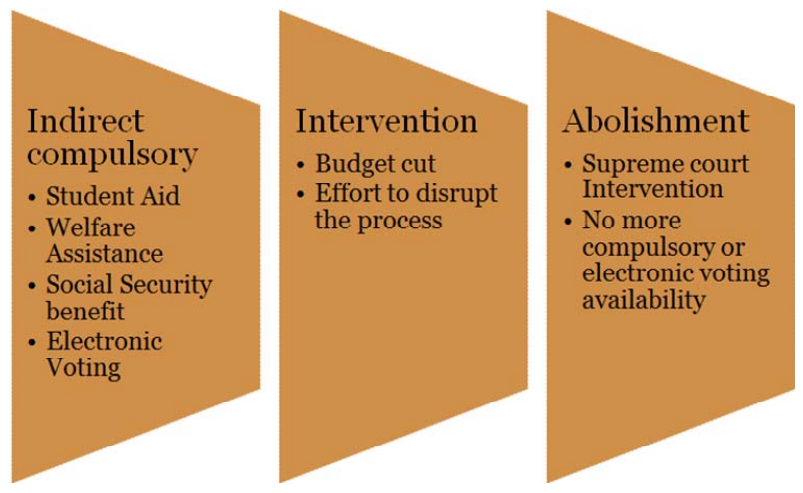

At the first stage, a law will be adopted slowly implementing the agenda of an Indirect Compulsory strategy. However, after we reach a certain turnout threshold, forces against the high turnout will realize how bad it is to have many people voting. With $40 \%$ of people voting in the USA, it cost politicians close to a trillion dollar during an election season. If over $60 \%$ of people cast their votes, the cost of campaigns and caving to interest groups will be tremendously affected for a politician. As a result, the Intervention Stage will kick in where forces against the high turnout will start introducing legal 
Table 2. Popularity of compulsory voting in Australia.

\begin{tabular}{cccc}
\hline Date of poll & Pollster & $\begin{array}{c}\text { In favour of } \\
\text { compulsory } \\
\text { voting (\%) }\end{array}$ & $\begin{array}{c}\text { Opposed to } \\
\text { compulsory } \\
\text { voting (\%) }\end{array}$ \\
\hline 1943 & Gallup & 60 & 35 \\
1969 & Gallup & 69 & 29 \\
1974 & Morgan & 60 & 36 \\
1996 & Herald McNair & 72 & 25 \\
2004 & Australian Election & 74 & 26 \\
2005 & Study 2004 & 71 & 28 \\
2005 & Morgan & 74 & 24 \\
\hline
\end{tabular}

Sources: Australian Gallup Polls, October 1943; Bulletin, 12 September 1995; Sydney Morning Herald, 9, 11 November 1996; Australian Election Study 2004; http://www.roymorgan.com/news/polls/2005/3901; Joint Standing Committee on Electoral Matters 2004, op. cit., p. 197.

changes to bring down the voter turnout. Politicians will pass laws to cut student loans and welfare funds, relaxing the mandate for an e-voting mechanism. But, if this intervention fails to destroy voter turnout growth, over a long period voter turnout will reach unexpected highs. This situation will make politicians vulnerable and special interest group almost powerless. As a result, hapless politicians and special interest groups will go to the Supreme Court. Hypothetically through their influence or balance of power in the court, the anti-high voter turnout group will eventually convince the court to rule against the provisions and make people vote for government assisted benefits thereby abolishing a mandate for evoting availability. The model shows some interesting results in the aftermath of this Supreme Court intervention period which I call "Abolishment”.

From a simplistic point of view, after Abolishment the turnout rate will go to back to $40 \%$ for US elections. However, the byproduct of the required voting period changes the voter turnout dynamics unprecedently. At first, people will vote for long periods because of mandate. Ironically, because of the habit forming aspect of voting [14], not all of them will stop voting post Abolishment. Secondly, higher turnout for a long period can influence many more new voters who do not fall under the mandate. A Harvard University poll said $61 \%$ of first-time voters polled in 2004 cited the importance of families and organizations in voting [15]. Researchers at Yale University and the University of Northern Iowa have demonstrated that social pressure can lead to higher voter turnout [16]. Furthermore, in a 2006 survey of first-time younger black voters, the National Coalition for Black Civic Participation Project found that first-time voters overwhelmingly cited families and community organizations as the most important influences in voting and becoming educated on the issues [17].

Therefore, this model demonstrates that if a voting requirement mandate stays in affect for long time, the system will build enough momentum to maintain and drive voter turnout even after a sharp drop following the Abolishment. Voter turnout declines post Abolishment are about $15 \%$ in this model. This value is close to the value we have observed in the Netherlands when they abolished the compulsory voting system after 50 years [7]. This model assumes positive growth is possible only if total turnout remains above 50\% after the Abolishment. In the first scenario (Figure 4), the mandate was in effect for 40 years and created enough natural and habitual voters because of the social factors and thus the system displayed positive gains after the Abolishment. However, in the second scenario (Figure 5), the mandate was in effect for only 20 years and it did not produce enough natural or habitual voters to maintain the growth post Abolishment.

\section{Analysis}

This proposed model shows a very promising outcome if Indirect Compulsory mandates are in effect for a long time. As seen in Australia, by 1921 they only had 54\% people voting and after compulsory voting mandate for the last 90 years, researchers are predicting that voter turnout will remain above $75 \%$ if the compulsory voting mandate is removed. This data indicates that to establish

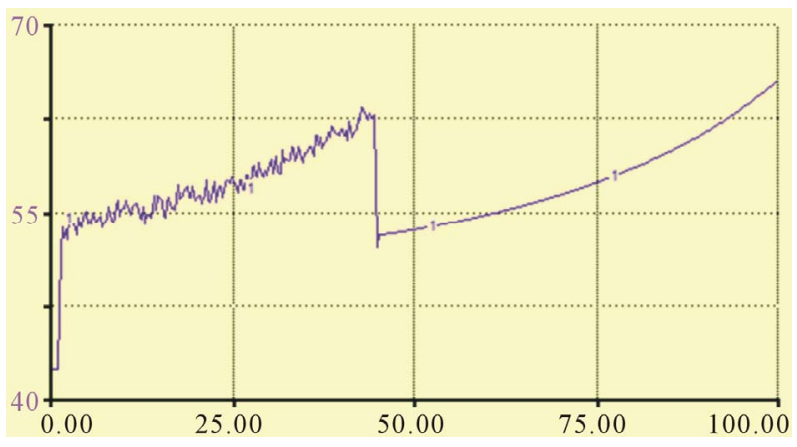

Figure 4. Mandate in effect for 40 years.

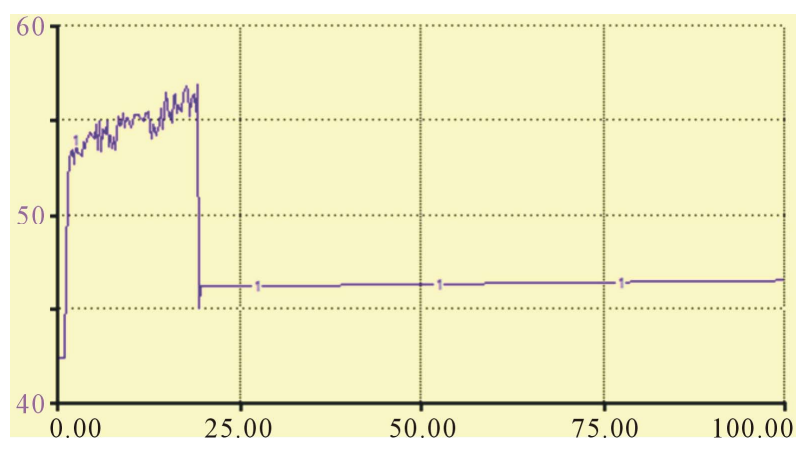

Figure 5. Mandate in effect for 20 years. 
a strong democracy, we need a mechanism making people participate in the election process before letting the process run without a mandate. Furthermore, indirect compulsory mechanisms can be viable techniques provided that Supreme Court intervention is delayed.

\section{Future Work}

Based on the assumptions that some invisible power acts against the will of the people, it favors low turnout to control election outcome. We can model this phenomenon for voter turnout using Lotka-Volterra equation [18] which is known as predator-prey equations.

$$
\begin{aligned}
& \frac{\mathrm{d} x}{\mathrm{~d} t}=x(\alpha-\beta y) \\
& \frac{\mathrm{d} y}{\mathrm{~d} t}=-y(\gamma-\delta x)
\end{aligned}
$$

- $y$ is the dark power and wants to contain voter turnout to control election outcome;

- $x$ is the democratic power-the percentage of people turns out to vote;

- $\quad \alpha, \beta, \gamma$ and $\delta$ are parameters representing the interaction of the two powers.

From various empirical research data and modeling system like this one, we need to calibrate the variables and apply this phenomenon in a much broader scale to various countries.

\section{REFERENCES}

[1] L. J. Diamond and M. F. Plattner, "Electoral Systems and Democracy,” Johns Hopkins University Press, Baltimore, 2006, p. 168.

[2] “Voter Turnout,” 2011. http://en.wikipedia.org/wiki/Voter_turnout

[3] L. Hill, "Low Voter Turnout in the United States. Is Compulsory Voting a Viable Solution?” Journal of Theoretical Politics, Vol. 18, No. 2, 2006, pp. 207-232. doi:10.1177/0951629806061868

[4] W. H. Riker and P. Ordeshook, "A Theory of the Calculus of Voting," American Political Science Review, Vol. 62, No. 1, 1968, pp. 25-42. doi:10.2307/1953324

[5] Wikipedia, “Compulsory Voting,” 2011.
http://en.wikipedia.org/wiki/Compulsory_voting

[6] Wikipedia, “Australian Federal Election 1925,” 2011. http://en.wikipedia.org/wiki/Australian_federal_election,_ 1925

[7] S. Bennett, "Compulsory Voting in Australian National Election,” Parliamentary Library Information Analysis and Advice for the Parliament, 2011.

http://www.aph.gov.au/library/pubs/rb/2005-06/06rb06.p df

[8] “Judge Strikes Down Healthcare Reform Law,” 2011. http://www.reuters.com/article/2011/01/31/us-usa-healthc are-ruling-idUSTRE70U6RY20110131?feedType=RSS\& feedName=healthNews

[9] R. G. Niemi and H. F. Weisberg, "Controversies in Voting Behavior,” 5th Edition, CQ Press, Washington DC, 2010, p. 31.

[10] L. Casper and L. Bass, “Too Busy to Vote,” Census Bureau-1998, 2011.

http://www.census.gov/prod/3/98pubs/cenbr984.pdf

[11] “M2SYS Delivers Rapid Fingerprint Integration Technology to Support Successful Deployment of Biometrically Controlled Nigerian Voting Project,” 2011. http://www.m2sys.com/pr021907.htm

[12] Wikipedia, “Selective Service System,” 2011. http://en.wikipedia.org/wiki/Selective_Service_System

[13] “Benefits and Programs Linked to Registration,” 2011. http://www.sss.gov/default.htm

[14] J. Fowler, "Habitual Voting and Behavioral Turnout," 2011.

http://jhfowler.ucsd.edu/habitual_voting_and_behavioral_ turnout.pdf

[15] "New Survey: First-Time Voters Propelled to Polls by Personal Contact,” 2011-12-10.

http://www.hks.harvard.edu/news-events/news/press-rele ases/new-survey-first-time-voters-propelled-to-polls-by-p ersonal-contact

[16] A. Gerber, D. Green and C. Larimer, "Social Pressure and Voter Turnout: Evidence from a Large-Scale Field Experiment," American Political Science Review, Vol. 102, No. 1, 2008, pp. 33-48. doi:10.1017/S000305540808009X

[17] “NCBCP 2006 Year-in-Review,” 2011. http://ncbcp.org/resources/reports/2006report.pdf

[18] Wikipedia, “Lotka-Volterra Equation,” 2011. http://en.wikipedia.org/wiki/Lotka-Volterra_equation 